$$
\text { "kokovay" — 2007/2/14 — 16:56 — page } 277 \text { — \#1 }
$$

\title{
E-learning in teacher training
}

\author{
Ágnes Kokovay and Andrea Kakuk
}

Abstract. A research has been organised with three Colleges taking part during the academic year of 2002-03. These institutions were

- The Teacher's Training College of Baja

- Eszerházy Károly College of Eger

- The College of Nyíregyháza

The aim of the research was to reveal differences between results of students studying in the traditional way and of students using e-learning.

The survey has been carried out among students of PE (physical education). A distance educational programme (Basics of Gymnastics) developoed before launching the survey served as basis for the survey [5]. The results of the research were first presented at the Agria-Média Conference in 2004. After analysing the results the findings were presented at the 3rd International Conference on Education and Information Systems in Orlando, Florida in July 2005.

This paper tries to reveal the structure of the e-learning programme, the environment of the research and the latest results found after the final analyses of the research.

Key words and phrases: e-learning, teacher training, PE teacher training.

ZDM Subject Classification: B50, C99.

\section{Introduction}

Soaring interest in e-learning in the past thirty years is not only attributable to the results of technology in pedagogy and the organization of education, and to the boost in enrolment to higher education, but also to the ever deeper crisis of education spreading the world over. After the economic recession of the 1970s

Copyright (C) 2006 by University of Debrecen 


$$
\text { "kokovay" — 2007/2/14 — 16:56 — page } 278 \text { — \#2 }
$$

a curb was put on the development of full-time education, since less money was appropriated from public funds for schooling.

A major contributory factor to the spread of e-teaching was the need for an educational structure which can adjust more flexibly to social needs.

It also promoted the search for new forms of education that the linear extension of traditional forms did not prove to be successful.

\section{Situation at the College of Nyíregyháza}

Tertiary education in Hungary is undergoing an enormous change. The complete restructuring of education confronts the institutions with enormous tasks. At the College of Nyíregyháza, one of the greatest problems is the increase of the enrolment by leaps and bounds. Originally planned for 3000 students, now it has an enrolment of 13 000. In spite of the large investment, and the infrastructural improvement since 2000, under the present conditions, teaching must reckon with a drop in the level of education.

No wonder that at universities and colleges - including The College of Nyíregyháza as well - there is a growing interest in new forms of education. A great part of these forms rests on a different financial basis or has a different economic structure, hence allowing for a decrease in costs required by the infrastructure of education [3].

While in traditional education, investment increases linearly with the rise in attendance, e-teaching education can be profitable provided that a certain critical number of student participation is reached. After a high investment cost, expense per student may decrease multiply. As for efficiency, experiments have shown that no significant difference can be found between the traditional and new forms [6].

In view of the above said, the management of the College of Nyíregyháza called tenders to devise the "Virtual Campus". The aim was to give all the lecturers of the College, who found interest in the programme a possibility to become specialists in e-teaching. The courses to be chosen were:

- Planner of e-learning systems

- Developer of e-learning curriculum

- Writer of e-learning materials

The tenders could be submitted on subjects of e-learning material, curricular structure, etc. The lecturers whose tenders were accepted took part in a threeterm course to acquire the theoretical and practical knowledge of e-teaching and 


$$
\text { "kokovay" — 2007/2/14 — 16:56 — page } 279 \text { — \#3 }
$$

learning. As the course was organised in distant form, the participants had a chance to experience both the advantages and the disadvantages of the method. The multimedia- teaching materials for e-learning have been worked out under this program.

\section{Presentation of an e-teaching program}

The didactic foundation of multimedia-based education is the control and motivation of the students' interest and attention. The adjustability of computer assisted teaching to the individual needs of the students and the scope of independence allows that the student depends primarily on the didactic conception of the program designer. The experiments so far have shown that students unfamiliar with an area, beginners and dependable students, need more guidance and control than advanced students. While beginners might get lost without a guidance, advanced students may regard this guide a hindrance in the learning process. It is therefore to be decided in an empirical way what extent of learning freedom and interactivity is to be provided.

When preparing the program, it was a precondition to know what preliminary knowledge the students have in the given material and how they can use the computer. It has been found that their knowledge was so meagre that it was negligible.

The program was therefore built linearly, although it does not preclude the possibility of navigation. The sections are built upon each other, but within each section, the direction of the progress is only partly regulated.

It was important to work out the adequate demonstration of the material. Various still and moving pictures were inserted for illustration [4] (see Figure 1, 2).

Figure 1

As the aim is to teach certain movements, it is essential to present real time exercises as well as sequences of exercises so that learners might get a clear view of the dynamics of movement. That is why motion pictures are built in the programmae. In picture one a sequence of exercises symbolised with a necklace can be seen. Since the exercises must be performed without delay by the students, the necklace was chosen as a visual analogy to stand for the different exercises. Each separate exercise is symbolised with a single bead. This way students realize that the exercises must be done without interruption.

In the next picture (Figure 2) 'soldiers' standing in a queue can be seen. Pupils standing in a formation like this are symbolised with circles, and the fine line represents the noses of the pupils. This way the direction of the face 
$\bigoplus$

"kokovay" — 2007/2/14 — 16:56 — page 280 — \#4

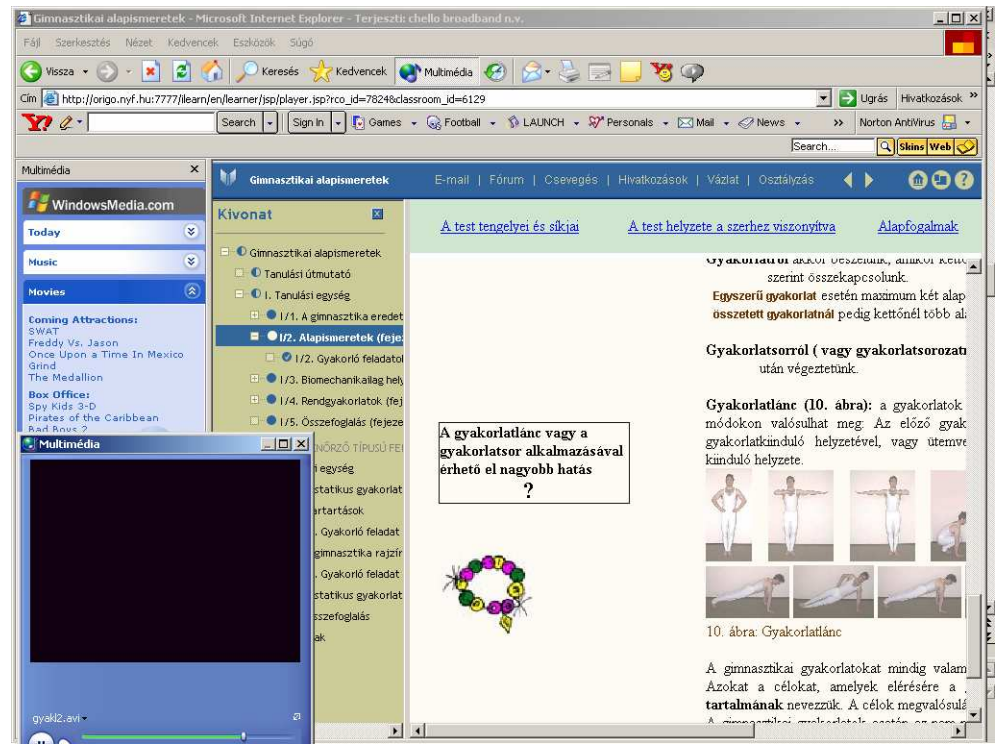

Figure 1. Moving Pictures

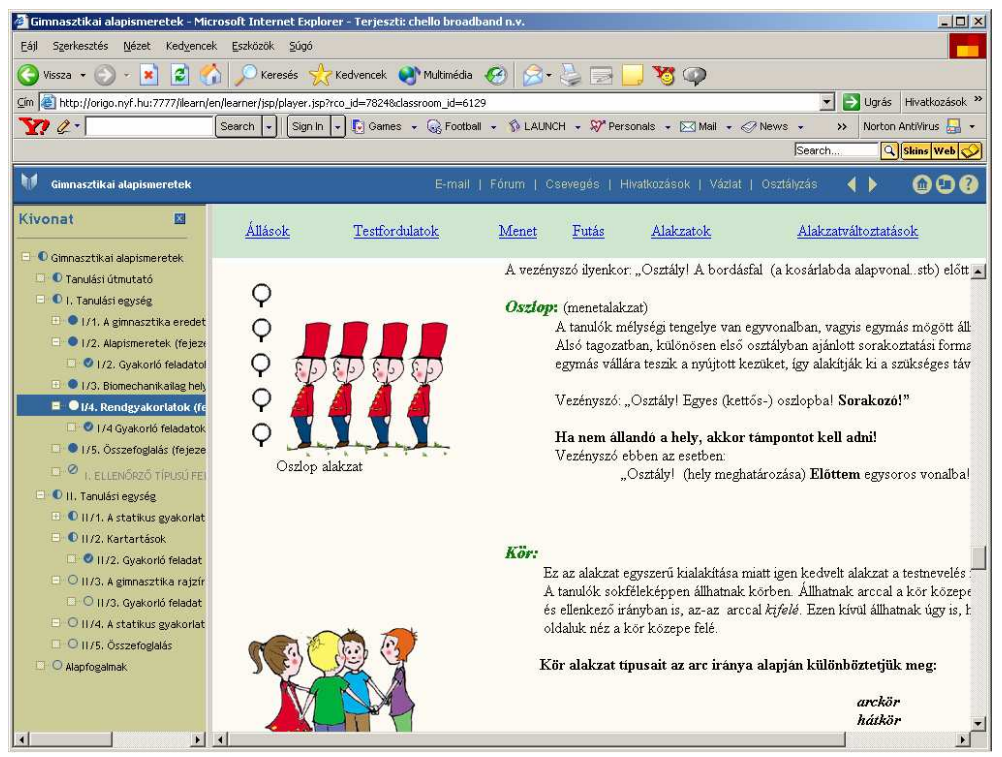

Figure 2. Visual analogies 


$$
\text { "kokovay" — 2007/2/14 — 16:56 — page } 281 \text { — \#5 }
$$

can be shown. This visual representation is essential to avoid accidents, and on the other hand these simple figures make it possible to plan the position of pupils in the gymnasium well in advance.

The main question was to decide on the format of the pictorial elements. We had to employ a system that did not need more machine performance than expected of average multimedia PCs. The greatest problem was the compacting of moving pictures. We employed a simple and limited system that could be installed on students PCs from the e-teaching program any time.

Since the goal is to teach movements, typical figures, drawings or emblems are attached to each sections of the material, partly to enhance learning performance and partly for clarity's sake. The sections are divided into distinct units, and the most important information is put in coloured frames, to enhance the major points (see Figure 3).

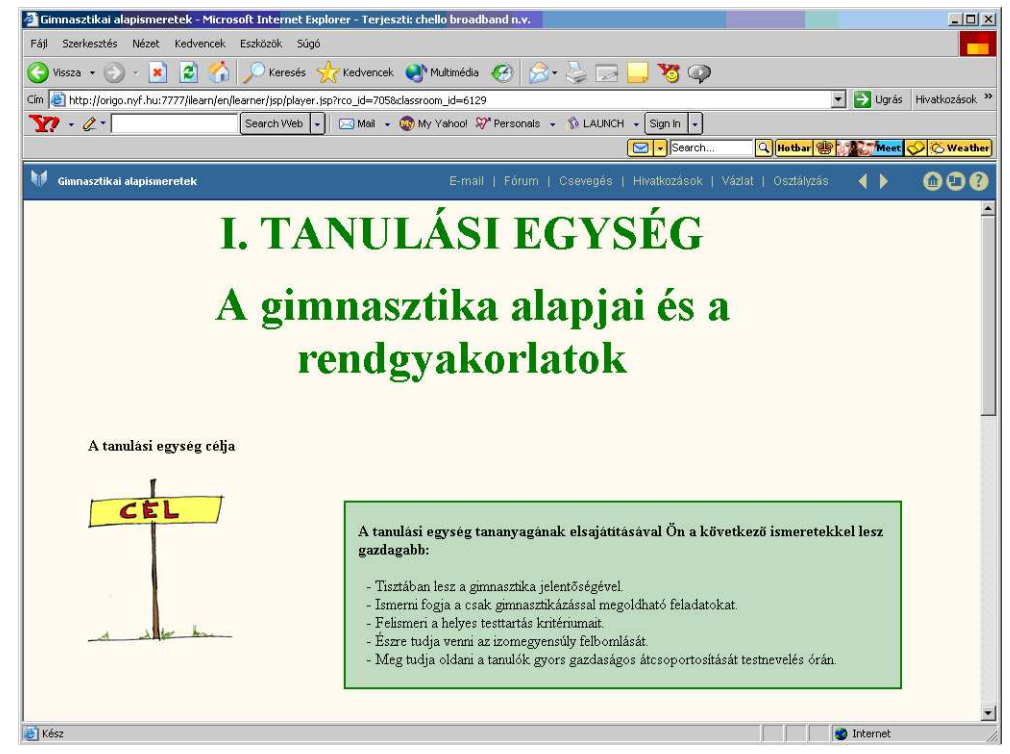

Figure 3. Important Information

Progress in the program is aided by the sketch that can be retrieved any time to give the user information about where he or she is in the material. It also shows which sections the student has completed and where he has still defects (see Figure 4). 


$$
\text { "kokovay" — 2007/2/14 — 16:56 — page } 282 \text { — \#6 }
$$

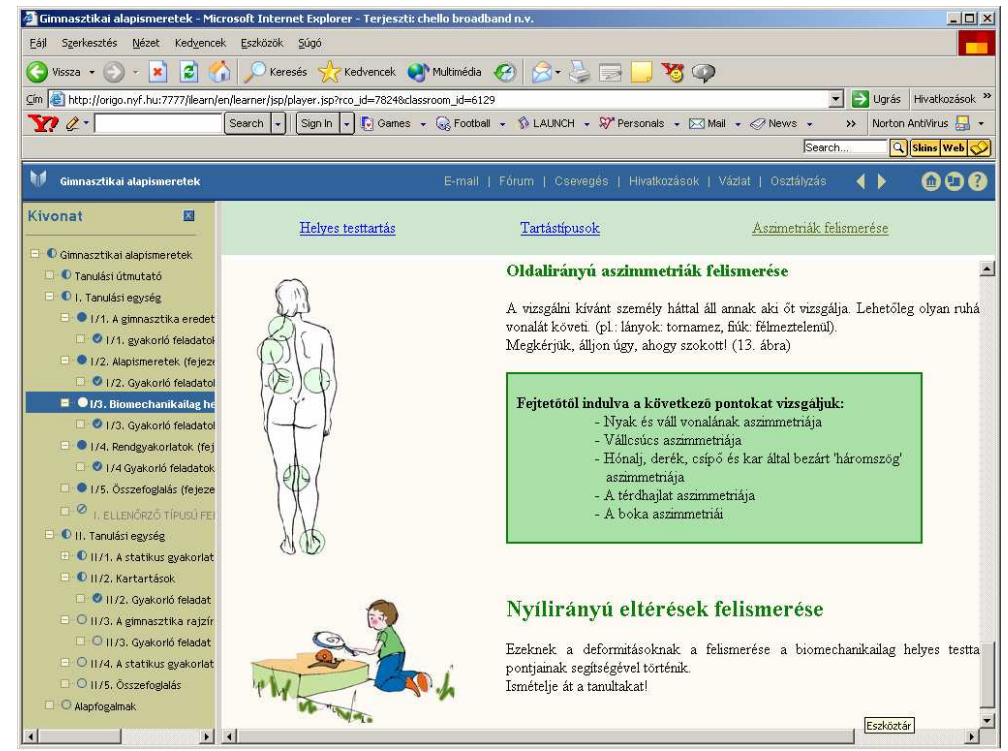

Figure 4. Navigation in the Material

\section{Figure 3}

The content of the first picture

I. TANULÁSI EGYSÉG: UNIT ONE

Basics of gymnastics and basic exercises

CÉL: AIM (this can be read on a yellow table)

In each and every unit the competences aimed to reach must be defined first. These competences can be read in green frames. In Unit One these competences are as follows:

After fulfilling the requirements of Unit One you'll be able to

- Relize the importance of gymnastics

- Identify the exercises that can be done only after doing gymnastics

- Recognise the criteria of the correct bearing of your body

- Regroup your pupils during your PE lesson

In the next picture (Figure 4) there is a sketch to help navigation within the whole material. It is a brown stripe in the left hand side of the picture from where you can reach any units of the whole material. There are small circles in front of the titles of the units. The colour of these circles show the level of fulfillment: totally white means totally unfulfilled, partly blue means the exercise is only partly done, while blue means the exercise is totally done. 


$$
\text { "kokovay" — 2007/2/14 — 16:56 — page } 283 \text { — \#7 }
$$

The light green strip at the top of the picture makes it possible to reach the main materials within the given units.

Each section is followed by exercises for practice and test questions. The exercises are selected by the machine at random from the collection of examples so that every major piece of information could be practiced. The exercises can be repeated at will but a section is only completed when at least $60 \%$ of the relevant exercises have been completed. The results of the exercises are immediately shown to the student, and if he wishes, he can take a look at his test after correction (see Figure 5, 6).

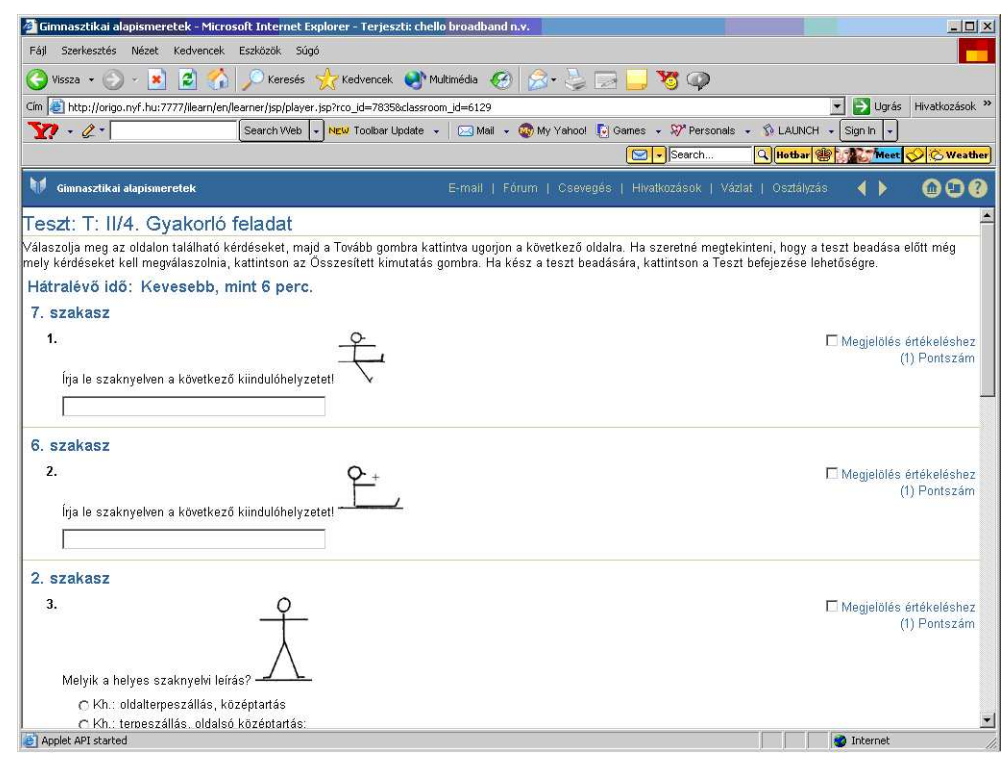

Figure 5. The Exercises

\section{Figure 5}

In this picture one of the self-check sequence of exercises can be seen. In the first picture students have to define the positions shown in the drawings.

The translation of the first exercise is given here as an example:

Stage 7 


$$
\text { "kokovay" — 2007/2/14 — 16:56 — page } 284 \text { — \#8 }
$$

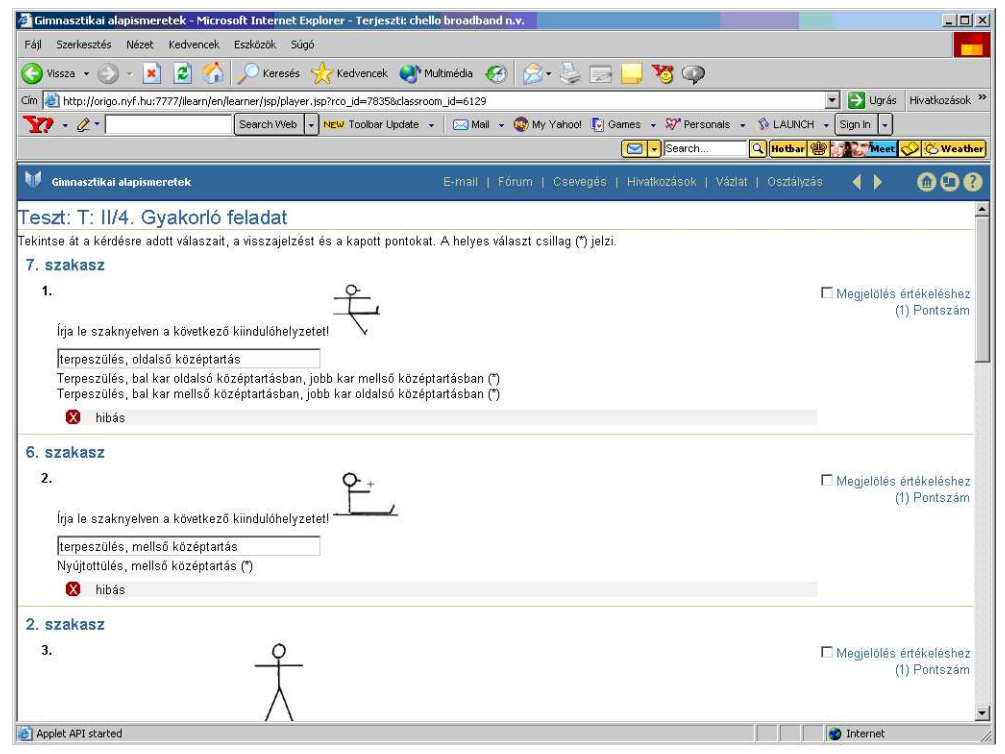

Figure 6. The Result of the Exercises

1.

Give the exact name of the following position

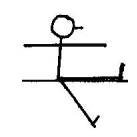

In the other picture (Figure 6) the solution can be seen. The programme automatically checks and corrects the students' solutions. Students can look at the correction immediately.

Exercise and solution

Stage 7

1.

Give the exact name of the following position

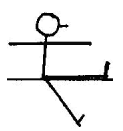

Straddle seat holding extended arms sideways

Straddle seat holding right arm sideway, left arm forward $(*)$

Straddle seat holding left arm sideway, right arm forward $(*)$

\section{(x) Wrong}

The task was not solved in the correct way by the student. The possible solution can be read in front of the signal "(*)". 


$$
\text { "kokovay" — 2007/2/14 — 16:56 — page } 285 \text { — \#9 }
$$

The completion of the exercise sheet endows the student with the right of doing the test. When the test has been completed, the exercises of the following section can be solved.

Since the student groups are geographically far from each other, we wished to make it possible for them to keep in touch. Right after having enrolled, we provide the students with a chat forum as well. It is chiefly a possibility for the users (here students) to keep in contact with each other.

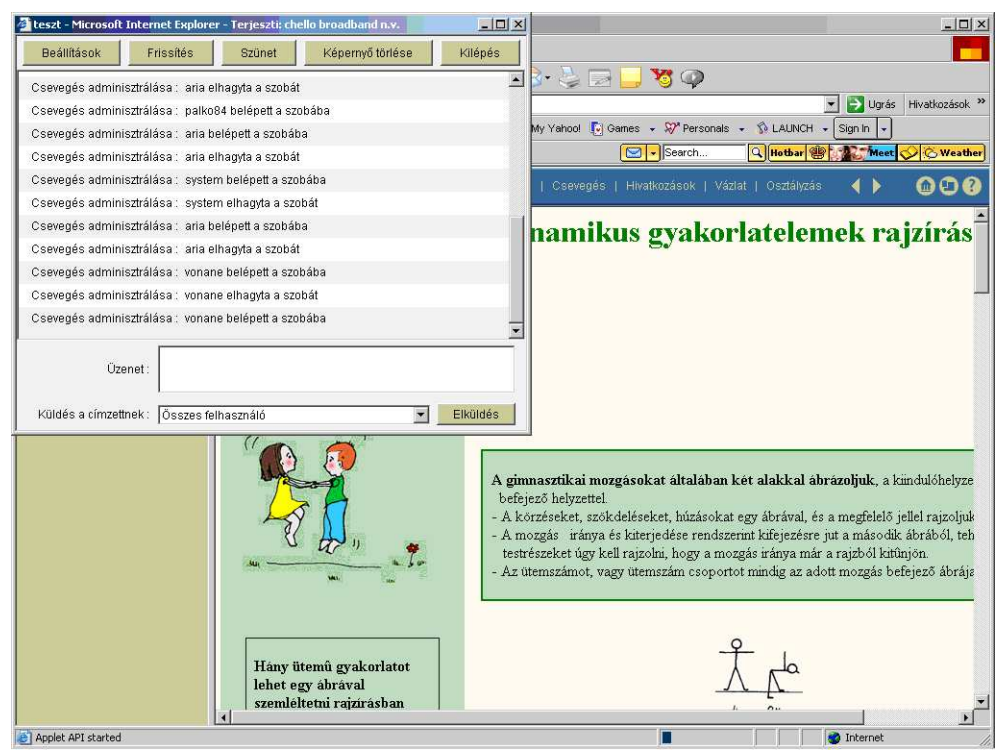

Figure 7. Chat

\section{Figure 7}

In the first picture you can find a chat forum in the upper left corner of the screen. This forum is similarly used as any other chat forums like this.

In the other picture (Figure 8) you can see one of the 'problem boxes' of the forum. Students might ask for help through these 'problem boxes'. Each and every question sent through these problem boxes is answered within 24 hours by the tutors.

Here is an example of a problem mentioned by one of the students:

"Good morning Ms.

I am inquiring about a problem. It is that we've done a test with a result of $70 \%$, but the system writes that it is $20 \%$ only, while it says that I've passed it successfully. Why is that so. Thank you for your answer in advance. Have a nice day! K. Sz." 


$$
\text { "kokovay" — 2007/2/14 — 16:56 — page 286 — \#10 }
$$

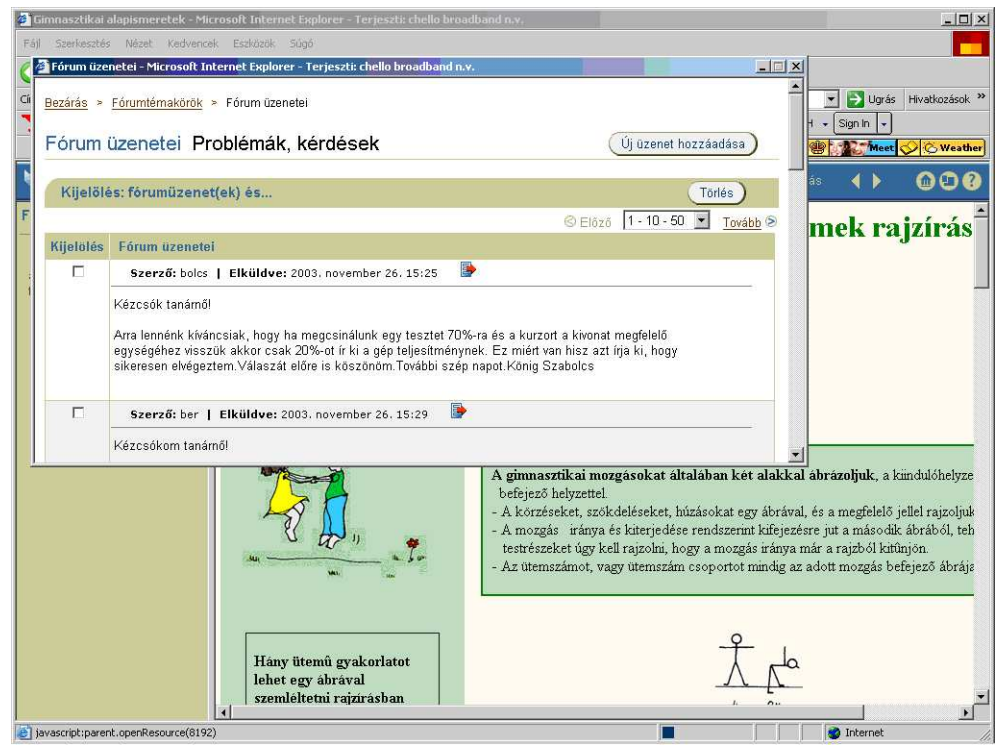

Figure 8. Forums

There is another forum via which they can keep in touch with the tutor of the programme and the maintainer of the system.

It is not negligible a question how the eyes are burdened during e-learning. As the vibration of the monitor and a badly chosen colour scheme might be very tiring, we have tried to choose as user-friendly a background colour as possible, and to apply colours that are closest to the natural hues.

\section{Aim of the experiment}

The aim is a comparison in efficiency between traditional education and multimedia distance learning with the help of the e-teaching program entitled 'Basics of gymnastics'.

\section{Questions}

Does multimedia e-teaching improve the efficiency of teaching gymnastics? Will the acquisition of basic movements be more accurate? 


$$
\text { "kokovay" — 2007/2/14 — 16:56 — page 287 — \#11 }
$$

Will the use of the technical language be more precise?

Will the learning activity of the students improve?

Will their motivation to learn be enhanced?

\section{Hypothesis}

The multimedia program of distance learning makes the teaching of gymnastics more effective in the following areas:

- it promotes the acquisition of the basics of gymnastics,

- it helps to acquire the professional jargon more accurately,

- the students' learning activity will be promoted,

- their learning motivation will be strengthened.

\section{The experimental samples}

In the first half of the academic year 2003/2004 the experiment was conducted at the teacher training colleges of Nyíregyháza, Eger and Baja. A part of the participants were students of physical education, another part were would-be primary-school teachers.

Distribution of participants by location and faculty (Table 1):

Table 1. Number of participants

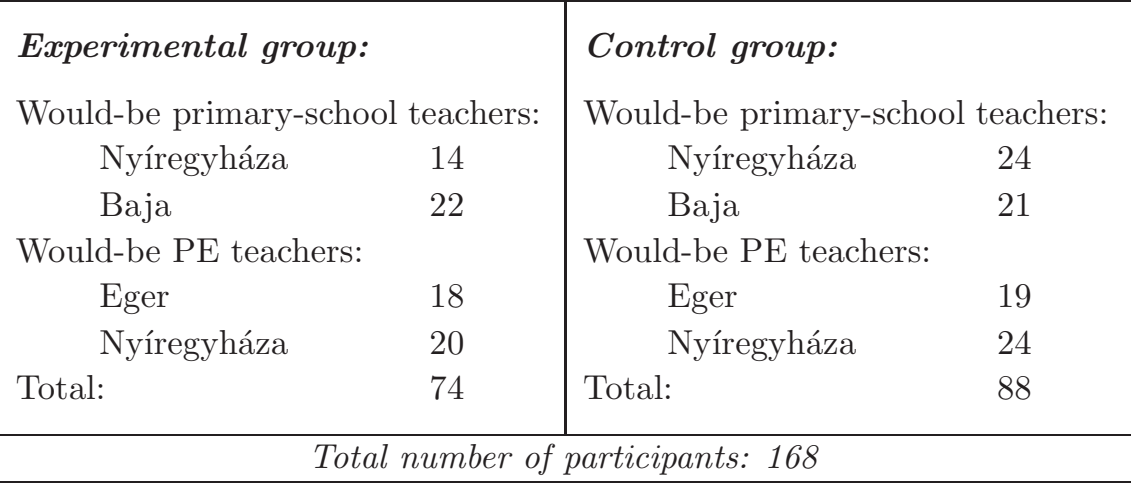




$$
\text { "kokovay" — 2007/2/14 — 16:56 — page 288 — \#12 }
$$

\section{Methods used during the experiment}

For the verification of the hypothesis I chose the pedagogical experiment as the principal research method.

Among the experimental methods, I found the compound two-group experiment as the most adequate tool because of its reliability. As several researchers have noted $[1,2]$ : its reliability owes to the mutual control exercised by the compound groups over one another, since the specificities of each subgroup of the experimental sample point at different directions. When these directions are identical within the main group, it verifies the unambiguous effect of the independent variable - here multimedia learning.

When, however, changes in different directions are discerned in the subgroups of the main experimental sample, then caution must be administered in evaluating the effect of the indepedent variable and further examinations may be necessary.

After the experiment the results of both the experimental and the control group have been checked by filling in a closing test. In analysing the results Pearson's Chi-Squere was used owing to the nominal nature of our data.

To explore the positive and the negative facts affecting the experiment a questionary has been filled in.

\section{The organisational structure of the closing test}

The test itself starts off with setting the code and place name used to identify the persons. The questionnaries were filled by the students with the use of these codes during the experiment to ensure students anonymity and avoid being prejudiced.

The end test applied during the experiment contained 35 questions with maximum 97 points to achieve. 14 of the questions examined knowledge based on rules and regularities (Table 2), while 21 questions measured the level of acquirements (the use of previously acquired knowledge (Table 3 ).

In both cases both open and closed questions nave been used, nevertheless there are more open questions among the questions measuring the level of acquirements.

Our choice was based partly on the technical literature [2] and partly on the experiences of the colleagues taking part in the experiment.

The analyses of the questions was carried out with the help of a computer. It was necessary to divide the questions, so during computer analyses the number of questions rose. 


$$
\text { "kokovay" — 2007/2/14 — 16:56 — page 289 — \#13 }
$$

Table 2. The questions of the final test measuring knowledge based on rules and Regularities (factual knowledge)

\begin{tabular}{|l|c|c|c|c|}
\hline \multicolumn{5}{|c|}{ Questions measuring knowledge based on rules and regularities } \\
\hline Unit & $\begin{array}{c}\text { Number of } \\
\text { questions }\end{array}$ & $\begin{array}{c}\text { Serial numbers of } \\
\text { questions }\end{array}$ & $\begin{array}{c}\text { Points per } \\
\text { questions }\end{array}$ & $\begin{array}{c}\text { Total } \\
\text { points }\end{array}$ \\
\hline Unit II & 6 & $4,16,17,18,21,30$ & $1,1,1,4,1,1$ & 9 \\
\hline Unit III & 3 & $1,2,23,24,31,32$ & $3,1,3,4,2,2$ & 15 \\
\hline Unit IV & 3 & $5,6,13,14,28$ & $1,1,4,3,1$ & 10 \\
\hline Unit V & 2 & 25,26 & 4,3 & 7 \\
\hline Total: & 14 & & & 41 \\
\hline
\end{tabular}

Table 3. The questions of the final test measuring knowledge based on rules and Regularities (factual knowledge)

\begin{tabular}{|l|c|c|c|c|}
\hline \multicolumn{5}{|c|}{ Questions measuring previously acquired knowledge } \\
\hline Unit & $\begin{array}{c}\text { Number of } \\
\text { questions }\end{array}$ & $\begin{array}{c}\text { Serial numbers of } \\
\text { questions }\end{array}$ & $\begin{array}{c}\text { Points per } \\
\text { questions }\end{array}$ & $\begin{array}{c}\text { Total } \\
\text { points }\end{array}$ \\
\hline Unit II & 2 & 19,20 & 5,4 & 9 \\
\hline Unit III & 7 & $10,11,12,22$ & $4,5,3,1$ & 15 \\
\hline Unit IV & 9 & $3,7,8,9,15,33,34$ & $1,4,5,3,2,3,3$ & 21 \\
\hline Unit V & 3 & $27,29,35$ & $1,2,10$ & 13 \\
\hline Total: & 21 & & & 56 \\
\hline
\end{tabular}

\section{Weight}

The work of the students while doing the tests was divided into the smallest units worth considering, to make the techniques of correction clear. As the smallest appreciable units could only be either good or bad, it made computer analysis easier.

One point was given each element of the exercises to make up our system of giving weights. If the task was to correct the description of a 4-rate exercise the student could get only 5 points. As the exercise could be divided into 5 separate sections; one is defining the starting point, plus defining the four rates (Table 4). 


$$
\text { "kokovay" — 2007/2/14 — 16:56 — page } 290 \text { — \#14 }
$$

Table 4. An example of weighting

\begin{tabular}{|c|c|c|}
\hline \multicolumn{3}{|c|}{ Question 8. Find the mistakes in the following description. } \\
\hline & Parts of the exercises & $\begin{array}{l}\text { Points per } \\
\text { parts of the } \\
\text { exercises }\end{array}$ \\
\hline 1 & starting point: sit stretched & 1 \\
\hline 2 & 1st rate: double arm flinging & 1 \\
\hline 3 & 2nd rate:trunk bending foreward & 1 \\
\hline 4 & 3rd rate: arm flinging backward & 1 \\
\hline 5 & 4th rate: pulling the arms backward in middle position & 1 \\
\hline & & 5 \\
\hline
\end{tabular}

\section{The reliability of the closing test}

The validity of the test was ensured by the definition of questions following the detailed analyses of the teaching material [2, p. 287]. As working out a detailed structural corporation and as well as the division of requirements can be considered the basic requirement as for e-learning/teaching materials are concerned, the same method was used to define the different phases and items of the tests.

The reliability of the test was examined during a previous experiment. The 'Kudre-Richardson 20' formula was used. The reliabilty index during the previuos experiment was 0.68. After corrections the test used in the experiment has risen up to 0.87 , which can be considered.

\section{Results}

The first hypothesis - that the students gain more thorough and accurate knowledge of gymnastics - has been verified.

On the basis of Pearson's Chi-Square there is a strong significant difference $(p<0.001)$, between the results of the experimental and the controll groups. The experiment proved the higher fulfillment of the experimental group (Table 5).

The results have been analysed on the basis of the hypothesis described above:

When comparing the results of the final test measuring knowledge based on rules and regularities no significant difference could be realised between the 


$$
\text { "kokovay" — 2007/2/14 — 16:56 — page } 291 \text { — \#15 }
$$

Table 5. The comparison of the results of the experimental and the control groups

\begin{tabular}{|l|c|c|c|c|}
\hline & $\boldsymbol{N}$ & Value & Standard deviance & Significance \\
\hline $\begin{array}{l}\text { Pearson } \\
\text { Chi-Squere }\end{array}$ & 161 & 89.823 & 51 & 0.001 \\
\hline
\end{tabular}

Table 6. Pearson's Chi Squers: The comparison of the results of the experimental and the control groups

\begin{tabular}{|c|c|c|}
\hline \multicolumn{3}{|c|}{ knowledge based on rules and regularities } \\
\hline Questions & $\boldsymbol{N}$ & Significance \\
\hline 1 & 161 & 0.110 \\
2 & 161 & 0.362 \\
4 & 161 & 0.344 \\
5 & 161 & 0.154 \\
6 & 161 & 0.520 \\
13 & 161 & 0.017 \\
14 & 161 & 0.000 \\
16 & 161 & 0.009 \\
17 & 161 & 0.556 \\
18 & 161 & 0.977 \\
21 & 161 & 0.000 \\
23 & 161 & 0.472 \\
24 & 161 & 0.454 \\
25 & 161 & 0.719 \\
26 & 161 & 0.301 \\
28 & 161 & 0.174 \\
30 & 161 & 0.175 \\
31 & 161 & 0.253 \\
32 & 161 & 0.317 \\
\hline
\end{tabular}

results of the experimental and the control group (Table 6). On the contrary a very strong difference could be seen when comparing the results of the final test in questions measuring previously acquired knowledge (Table 7) In both cases - 
apart from very few exceptions - the results of the experimental group proved to be higher.

Table 7. Pearson's Chi Squers: The comparison of the results of the experimental and the control groups

\begin{tabular}{|c|c|c|}
\hline \multicolumn{3}{|c|}{ previously acquired knowledge } \\
\hline Questions & $\boldsymbol{N}$ & Significance \\
\hline 19 & 161 & 0.024 \\
20 & 161 & 0.028 \\
10 & 161 & 0.047 \\
11 & 161 & 0.030 \\
12 & 161 & 0.311 \\
22 & 161 & 0.002 \\
3 & 161 & 0.000 \\
7 & 161 & 0.017 \\
8 & 161 & 0.048 \\
9 & 161 & 0.311 \\
15 & 161 & 0.038 \\
33 & 161 & 0.022 \\
34 & 161 & 0.007 \\
27 & 161 & 0.000 \\
29 & 161 & 0.025 \\
35 & 161 & 0.013 \\
\hline
\end{tabular}

- As for planning gymnastics exercises significant differences could be traced: effect mechanisms are clearer for those in the experimental group.

- The experimental group proved to be better in planning the introductory part of the PE lessons as well.

- Those in the control group (45.5\%) delt with the material only before the testing, while those in the experimental group have been preparing continuously. $90.4 \%$ of the students have learnt or practised several times, but at least once a week using the advantage of the programme (Table 8).

- Continuous practicing and learning had a positive effect on the learning motivation of the students in the experimental group. It can be presumed that 


$$
\text { "kokovay" — 2007/2/14 — 16:56 — page } 293 \text { — \#17 }
$$

Table 8. Learning habits of the students taking part

\begin{tabular}{|l|c|c|c|c|}
\hline \multirow{2}{*}{ Frequency } & \multicolumn{5}{|c|}{ FEARNING HABITS } \\
\cline { 2 - 5 } & $\begin{array}{c}\text { Experimental } \\
\text { group }\end{array}$ & $\begin{array}{c}\text { Controll } \\
\text { group }\end{array}$ & $\begin{array}{c}\text { Experimental } \\
\text { group }\end{array}$ & $\begin{array}{c}\text { Controll } \\
\text { group }\end{array}$ \\
\hline monthly & 7 & 11 & $9.58 \%$ & $12.30 \%$ \\
\hline weekly & $\mathbf{5 9}$ & 5 & $\mathbf{8 0 . 8 2 \%}$ & $\mathbf{5 . 6 8 \%}$ \\
\hline every day & $\mathbf{1}$ & - & $\mathbf{1 . 4 0 \%}$ & - \\
\hline very other day & $\mathbf{6}$ & & $\mathbf{8 . 2 1 \%}$ & - \\
\hline occassionally & - & $\mathbf{3 2}$ & - & $\mathbf{3 6 . 3 6 \%}$ \\
\hline $\begin{array}{l}\text { occassionally } \\
\text { before an exam }\end{array}$ & - & $\mathbf{4 0}$ & - & $\mathbf{4 5 . 4 5 \%}$ \\
\hline
\end{tabular}

these positive effects were further enhanced by the positive changes as far as the personal results are concerned. We have come to this conclusion on the basis of the results proved by the the programme on the one hand, and on the other hand by the answers given to the questionary.

On the basis of the findings above it can be stated that the method (elearning) used in the experiment has had a very positive effect on the results of the students involved in the experiment. (A further and more detailed analyses of the experiment will be aviable in the library of the Department of Physical Education of Semmelweis University from 2006 September.)

\section{Summary}

The experiment presented above has tried to focus attention on an unusual field where e-learning can be effectively used.

The modernization of education is one of the most pressing tasks of our days. The rapid advancement of information and communication technologies and the radical transformation of the market expectations urge the institutions of education, the teachers and students to press for renewal.

Traditional education is gradually giving way to learning management, as the role of independent, self-governed learning increases continuously. Though the rate of e-learning is not expected to rise as immensely as it was supposed earlier, 


$$
\text { "kokovay" — 2007/2/14 — 16:56 — page 294 — \#18 }
$$

it is still a great chance to extend education to those who otherwise wouldn't have any possibility to learn [8].

The nature of knowledge is also changing, assuming a multimedial and practical character. The instruments of information and communication technology are rapidly penetrating our everyday life, enabling, and also demanding the transformation of the pedagogical environment, the knowledge and use of up-to-date informatic tools.

\section{References}

[1] Falus Iván, Didaktika, Nemzeti Tankönyvkiadó, Budapest, 1999.

[2] Falus Iván, Bevezetés a pedagógiai kutatás módszereibe (Introduction to the methodology of pedagogical research), Müszaki könyvkiadó, Budapest, 2000, 287-289.

[3] Galó Miklós, A Bologna folyamat végrehajtásának feladatai és dilemmái (The tasks and dilemmas of the execution of the Bologna Process), vitaanyag (material for discussion), Nyíregyházi Főiskola, 2003.

[4] Kokovay Ágnes, A gimnasztika szaknyelve, szakleírása és gyakorlatközlési módszerei (The language and description of gymnastics), Bessenyei Könyvkiadó, Nyíregyháza, 1997.

[5] Kokovay Ágnes, A gimnasztika alapjai (Basics of gymnastics), távoktató tananyag (a distance educational programme), 2001, http://origo.nyf.hu:7777.

[6] H. Neber, A. Wagner, W. Einsiedler (Hrsg.), Selbstgesteuertes Lernen, Beltz Verlag, Weinheim und Basel, 1978, 38-42.

[7] Szakadát István, Xanadu, in: ABCD Interaktiv Magazin, 1995.

[8] Tompa Klára, A korszerű oktatástechnológia jellemzői (The characteristics of modern educational technology), in: Dr. Benedek András, Oktatáselméleti kísérletek a szakképzésben (Questions relating to educational theory in vocational training), Müszaki Kiadó, 1999, 63-83.

ÁGNES KOKOVAY and ANDREA KAKUK

COLLEGE OF NYÍREGYHÁZA

H-4400 NYÍREGYHÁZA

31/B SÓSTÓI STR.

HUNGARY

(Received January, 2006) 